\section{Microbial, chemical-physical, rheological and organoleptic characterisation of roe deer (Capreolus capreolus) salami}

\author{
David Ranucci, Rossana Roila, \\ Dino Miraglia, Chiara Arcangeli, \\ Francesca Vercillo, Sara Bellucci, \\ Raffaella Branciari
}

Department of Veterinary Medicine, University of Perugia, Italy

\begin{abstract}
Game meat and related products are important in the promotion of local economies and rural areas. Microbiological, chemical-physical, rheological and sensory characteristics of fermented meat products (salami) made by different percentages of pork and hunted roe-deer (Capreolus capreolus) meat were evaluated. The microbiological determination indicated that the products are safe to eat, as neither Listeria monocytogenes nor Salmonella spp. was isolated from the samples. The hygienic adequacy of the process was guaranteed, as there was below $3 \log \mathrm{CFU} / \mathrm{g}$ of Enterobacteriaceae level in the final products. The proximal composition analyses showed lower lipid levels in comparison to pork salami. The difference in chemical composition affects the rheological and sensory traits of the final products; the products were harder and with higher gumminess when $50 \%$ of roe-deer meat was used. Game meat flavour and odour increased with the increasing percentage of roe-deer meat.
\end{abstract}

\section{Introduction}

Proper management of the wildlife is fundamental in the protection of biodiversity, the promotion of local economies and the defence of urban territories against the increasingly frequent movement of wild ungulates outside of their natural habitats (Ramanzin et al., 2010). Game meat plays an important role in enhancing the typicality, tradition and linking of animal production with the territory, and this also allows for touristic promotion, both from a culinary and cultural perspective, which in turn, affects the regional economy (Tomasevic et al., 2018). The significant increase in wild ungulate populations in Europe has led to an increase in the hunting season, with a consequent increase in the consumption of meat and meat-derived products, resulting in a conservation and management approach of wildlife rather than protection (Quirós-Fernández et al., 2017). Therefore, game meat can not only be a resource to be allocated primarily to self-consumption, but it must be managed in a conscious and shared way through the validation of a structured supply chain to increase its competitiveness and sustainability (Hoffmann and Wiklund, 2006). In this sense, it is of fundamental importance to validate the processes of killing, transport and treatment of carcasses, as well as those of meat processing, through microbiological and chemicalphysical analyses, to integrate a scientific and objective approach to the traditional salami making, which does not always allow to obtain a safe and guaranteed product (Kuhn et al., 2011).

Although the game meat trade is still very limited, and heavily dependent on the hunting seasons and the established hunting rates, there is an increasing market availability of meat products of the different game species, especially those of wild boar, deer and fallow (Paleari et al., 2003). Several studies have been conducted on the microbiological, chemical-physical, rheological and sensory characteristics of game meat products (Capita et al., 2006; Chakanya et al., 2018; Karwowska and Dolatowski, 2017; Paleari et al., 2002, 2003; Soriano et al., 2006), but works on roe-deer meat products are scarce.

This paper aims to define the microbiological, chemical centesimal composition, rheological and sensory characteristics of fermented meat products (salami) made with different percentages of pork and roedeer (Capreolus capreolus, Linnaeus 1774) meat.

\section{Materials and Methods}

Adult roe-deer males were hunted from April to June 2018 between the municipalities of Gubbio and Gualdo Tardino (Umbria Region, Central Italy). After the hunting, animals were promptly on-field exsanguinated and eviscerated, and then transferred to a collection centre for carcass storage. After resting in a cell at $2^{\circ} \mathrm{C}$ for between 1 and 6 days (average 4 days), the carcasses were transferred to the local slaughterhouse for skinning and sectioning, and then to a local producer for fermented meat (salami) production (Fazi Carni, Gualdo Tadino, Italy). Salami were made according to the local tradition: the deboned roe-deer meat was combined with pork meat (mainly belly and shoulders) and minced in $6 \mathrm{~mm}$ fragments. The meat was
Correspondence: Dino Miraglia, Department of Veterinary Medicine, University of Perugia, Via San Costanzo 406126 Perugia, Italy.

Tel.: +39.0755857932.

E-mail: dino.miraglia@unipg.it

Key words: Game meat, Meat fermented products, Food safety, Food quality, Wildlife.

Acknowledgement: This paper is a part of a research project (PSR Umbria 2014-2021, misura 16.2, EcoSelvoFiliera: Ruralità e valorizzazione qualitativa delle carni degli ungulati selvatici) founded by the European Commission, through the Umbria Region (Italy), to develop rural agriculture and animal production in the member states. The authors wish to thank Dr. Alessandro Monacelli at Serra Brunamonti S.r.l. for his significant support in the organization of the project, and $\mathrm{Dr}$. Fausto Cambiotti for the samples collection.

Conflict of interest: the authors declare no potential conflict of interest.

Funding: PSR Umbria 2014-2021, misura 16.2 EcoSelvoFiliera: Ruralità e valorizzazione qualitativa delle carni degli ungulati selvatici.

Received for publication: 29 March 2019

Revision received: 10 May 2019.

Accepted for publication: 16 May 2019.

This work is licensed under a Creative Commons Attribution-NonCommercial 4.0 International License (CC BY-NC 4.0).

(C) Copyright: the Author(s), 2019

Licensee PAGEPress, Italy

Italian Journal of Food Safety 2019; 8:8195

doi:10.4081/ijfs.2019.8195

then mixed with salt $(2.2 \%)$, pepper powder and pepper grains $(0.2 \%)$, garlic $(0.05 \%)$ and starter cultures (Eurostarter MI Rapid, MEC Import, Roma, Italy; a mix of Staphylococcus xylosus and Staphylococcus carnosus + Lactobacillus sakei in a 2:1 ratio). Neither antioxidant nor preservatives were added to the minced meat. After storing overnight at $4{ }^{\circ} \mathrm{C}$, the meat was stuffed into a previously rehydrated dry-salted natural swine intestine. Following 10 days of drying inside hot chambers $\left(22^{\circ} \mathrm{C}\right.$ and $62 \%$ relative humidity $(\mathrm{RH})$ for $48 \mathrm{~h} ; 19^{\circ} \mathrm{C}$ and $66 \% \mathrm{RH}$ for $76 \mathrm{~h}$, followed by a $1^{\circ} \mathrm{C}$ temperature reduction and $1 \%$ increase in the $\mathrm{RH}$ each day, so as to reach $15^{\circ} \mathrm{C}$ and $72 \%$ RH within 10 days), the products were ripened in controlled seasoning rooms at $13^{\circ} \mathrm{C}$ and $75 \% \mathrm{RH}$ for 60 days. The products were obtained from three different percentages of roe-deer and pork meat: $50 \%$ roe-deer meat and 50\% pork meat (high percentage: $\mathrm{SH}$ ), $33 \%$ roe-deer meat and $67 \%$ pork meat (low percentage: SL), and $100 \%$ 
pork meat (control: SC).

The experiment was repeated after 1 month, with the same production technique and meat proportion in the products as indicated above, to obtain a replicate batch.

Immediately after stuffing (T0) and at 7 (T1), 14 (T2), and 60 days (T3), five samples from each product (SL, SH, SC) were collected and transported under refrigeration condition to the laboratory for the analytical determination.

\section{Microbiological analyses}

Three samples, for each time considered, were tested in triplicate for: i) Enterobacteriaceae count, by following the ISO 21528-2 (ISO, 2004) method; ii) Enterococcus spp. count, by plating diluted samples on Slanetz-Bartley agar (Biolife Italiana, Milan, Italy) and incubation at $37^{\circ} \mathrm{C}$ for $48 \mathrm{~h}$; iii) Sulphite-reducing bacteria, according to the ISO 15123 (ISO, 2003) assay; iv) Lactic acid bacteria (LAB) count, as detailed in the ISO 15124 (ISO, 1998) method; v) Micrococcaceae count, by plating diluted samples on mannitol salt agar (Biolife Italiana, Milan, Italy) and incubation at $37^{\circ} \mathrm{C}$ for $24 \mathrm{~h}$

The average values of the counts obtained from all the products and at all the times considered were calculated and converted into log colony-forming units (CFU)/g. Furthermore, Listeria monocytogenes and Salmonella spp. were isolated by using the ISO 11290-1 (ISO, 2017a) and ISO 6579-1 (ISO, 2017b) procedures, respectively.

\section{Chemical-physical analyses}

On the other two samples per batch, proximal analyses and salt $(\mathrm{NaCl})$ content were determined, based on the AOAC method (AOAC, 2000). This assay was also performed at the end of the ripening time in all the products, in triplicate.

$\mathrm{pH}$ and water activity $\left(a_{w}\right)$ were measured according to Branciari et al. (2016), at each sampling time for all the products of the trials, using a $\mathrm{pH}$ meter (Crison $\mathrm{pH} 25$, Crison, Barcelona, Spain) and hygrometer (AquaLab CX-3, Decagon Pullman, WA, USA), respectively. The International Commission on Illumination (CIE, 1976) $L^{*} a^{*} b^{*}$ colour space values were recorded using a Minolta C400 chromameter (Minolta Ltd., Osaka, Japan), with six measures taken on the surface of three slides for each sample belonging to each product type considered, at the end of the ripening time.

\section{Rheological analyses}

From each product collected at the end of the ripening time, three cylinders with a height and width of $2.5 \mathrm{~cm}$, were removed using a core drill. A texture analyser (TVT
6700, Perten Instrument, Sweden) was equipped with a cylindrical probe $(3 \mathrm{~cm}$ in diameter), and the relative settings were set. The compression rate used was $30 \%$, with a probe speed rate of $2 \mathrm{~mm} / \mathrm{s}$. The parameters considered were hardness, resilience, cohesiveness, gumminess and chewiness, according to user's manual (Perten Instrument Method Description: TVT method 47-01.02).

\section{Sensory analyses}

A panel comprising 12 assessors, were trained according to the ISO 8586 (ISO, 2012) criteria. In the same session, the attributes to be evaluated for each sample were defined, and parameters were selected to identify the visual, olfactory, gustative characteristics, consistency and acceptability of the different product types.

The test was repeated on the final products (SH, SL, SC) of the two different batches on different days, using specific questionnaires. To quantify the intensity of each attribute, a 9-point scale was used, in which $0=$ minimum intensity and $9=$ maximum intensity, as detailed in the ISO 13299 (ISO, 2016). The panel test was conducted as reported by Ranucci et al. (2018). The evaluators tasted the products samples that had been sliced to a thickness of $2 \mathrm{~mm}$ and pre-equilibrated at room temperature for about $1 \mathrm{~h}$. The samples were served anonymously on white plastic plates and coded with random three-digit numbers. The evaluations were carried out with repeated tastings, and water and crackers were served to allow the assessors to give a more objective judgment, eliminating the flavours deriving from the taste of previous samples.

\section{Statistical analyses}

Data were subjected to analysis of variance (ANOVA) (GMP, SAS Institute, Cary, NY, USA), considering, as factors, the microbiological and chemical-physical data monitored over time, the treatment $(\mathrm{SH}, \mathrm{SL}$, $\mathrm{SC}$ ) and the sampling time (T0, T1, T2 and T3). For the other determinations, carried out exclusively on the finished product, a one-way ANOVA was used, with the treatment as a fixed factor. Tukey's post hoc test was used to determine if the values obtained were different at a significance level of 0.05 .

\section{Results and Discussion}

The hygienic-sanitary level of the tested products was adequate, as regards the evaluation of food safety criteria (EC Regulation 2073/2005 and s.m.i.) since in all the samples analysed, regardless of the product type and sampling time, L. monocytogenes and Salmonella spp. were not detected. The presence of these two pathogens in game meat products are reported in the literature (Cenci Goga et al., 2012; Kuhn et al., 2011; Lucchini et al., 2014) but a frequency variation across populations may be present (Avagnina et al., 2012). Besides, the implementation of good hygienic practice throughout the game meat chain could reduce the presence of both pathogens on wild ruminants' carcass (Paulsen et al., 2012) and, therefore, in the products. Furthermore, during salami processing, the condition of the production could affect the survival of Salmonella spp. in the final products (Cenci Goga et al., 2012). The Enterobacteriaceae and Enterococcus spp. counts are reported in Figure 1.

The level of Enterobacteriaceae was quite high in the mixture, with values around $4 \log \mathrm{CFU} / \mathrm{g}$ in all the products at T0. Subsequently, due to changes in the chemical-physical parameters and the development of competitive flora (Paleari et $a l ., 2002)$ the values decreased to less than $3 \log \mathrm{CFU} / \mathrm{g}$. The Enterobacteriaceae count tended to be less in the product with $50 \%$ roe-deer meat, and this trend was significantly evident at T0, T1 and T2 in these salami $(\mathrm{P}<0.05)$. Since the presence of Enterobacteriaceae is mainly linked to faecal contamination during slaughter operations (Chakanya et al., 2018), it is possible to attribute the variation in the Enterobacteriaceae counts across the different products to the raw pork meat. Moreover, in pigs, due to the adopted slaughtering system, the hygienic criteria of process hygiene, including the Enterobacteriaceae count (EC Regulation 2073/2005 and s.m.i.), are higher than those of other animal species.

No difference in the Enterococcus spp. counts $(\mathrm{P}>0.05)$ were registered between the samples, and the recorded values were maintained at between 2 and $3 \log \mathrm{CFU} / \mathrm{g}$ over time, in all the samples considered. The values were lower than those registered in some traditional Italian salami (Branciari et al., 2016; Ranucci et al., 2013). The Micrococcaceae and LAB counts are reported in Figure 2. The micrococci count in all the tested groups were already high at the time of the casing (Figure 2), and irrespective of the characteristics of the meat adopted, in view of the use of starter culture directly added to the mix. This population remained stable for the first three sampling times with variation only at T3. Generally, this population tends to fall in the first week of seasoning, concomitantly with the 
growth of the LAB (Capita et al., 2006) but this behaviour was not apparent in the products under the experiment conditions of the current study. However, in the first week of fermentation, the $\mathrm{pH}$ (Figure 3) also maintained rather high values compared with other fermented meat products described in the literature (Zanardi et al., 2004). Interestingly, in products with a high percentage of roe-deer meat (SH), the micrococci population tended to remain significantly higher at $\mathrm{T} 3$ when compared with SL and SC $(\mathrm{P}<0.05)$. The presence of such microorganisms is responsible for the increased proteolytic activity, which confers aromatic traits to the product and lowers the acidity (Mauriello et al., 2002).

A rapid growth of the LAB occurred, already reaching $8 \mathrm{log} \mathrm{CFU} / \mathrm{g}$ at 1 week after production. This trend is typical in this kind of meat product (Połka et al., 2015) but no difference was found between the different groups.

Sulphite-reducing bacteria (at less than $2 \log$ CFU/g) were found exclusively in the products after casing (T0) and in some salami samples, with no difference between the control and products with roe-deer meat.

As shown in Figure 3, there was a rapid decrease in the $\mathrm{pH}$ of the products within the first week of production, followed by an increase, as the seasoning progressed. This phenomenon is attributable to the gradual increase in acidity linked to the fermentative metabolism of the $\mathrm{LAB}$, and then by the onset of proteolytic events due to Micrococcaceae (Wang et al., 2015). One characteristic of the products is a lowmedium acidity $(\mathrm{pH}>5$ after casing and $\mathrm{pH}$ around 6 in the final products) and intense proteolysis, typical of various traditional Italian products (Cenci Goga et al., 2008; Miraglia et al., 2017). This characteristic was most pronounced in both SL and SH, in which, at the end of ageing, statistically higher $\mathrm{pH}$ values were observed than in the control $(\mathrm{P}<0.05)$. Conversely, the counts of Micrococcaceae, which are mainly responsible for the proteolytic phenomena (Połka et al., 2015), were also higher in SL and SH than the control.

The $a_{w}$ values are reported in Figure 4. The gradual loss of water from the product during the drying and seasoning steps means less water available for the microorganisms to grow and survive. These data are comparable to those obtained in other experiments (Branciari et al., 2016; Capita et al., 2006; Soriano et al., 2006). No significant differences between the control and treated salami were registered, showing that the product formulation did not influence the $a_{w}$ level. The low $a_{w}$ value in the final product contributes to improving product
$\boldsymbol{A}$

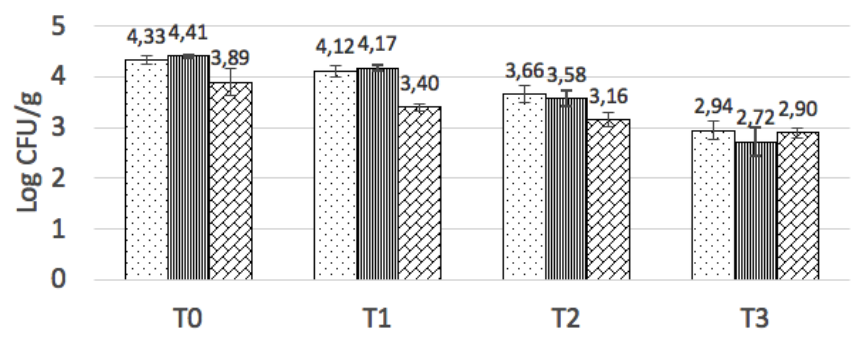

$\square \mathrm{SC} \quad$ 而SL $\quad$ 圆 $\mathrm{SH}$

$\boldsymbol{B}$

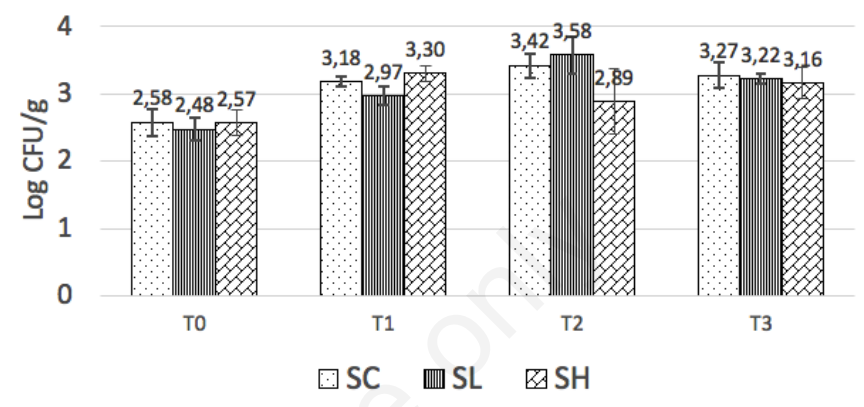

Figure 1. Enterobacteriaceae (A) and Enterococcus spp. (B) counts in roe-deer salami and pork salami. SC (control:100\% pork meat); SL (low percentage: 33\% roe-deer meat and $67 \%$ pork meat; $\mathrm{SH}$ (high percentage: $50 \%$ roe-deer meat and $50 \%$ pork meat; T0 (immediately after stuffing); T1 (at 7 days storage), T2 (at 14 days storage); T3 (at 60 days storage).

\section{A}

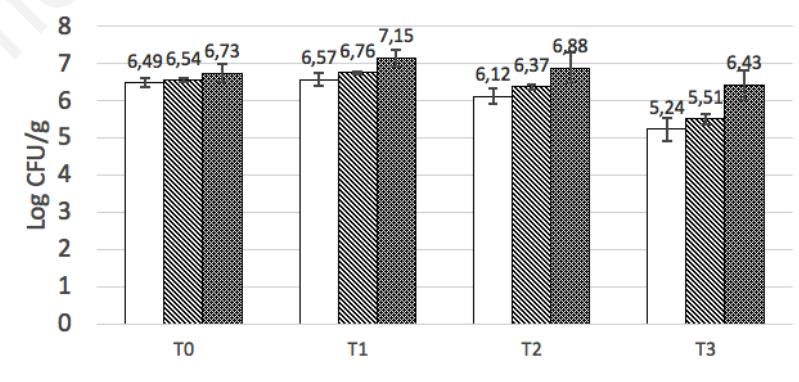

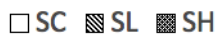

B

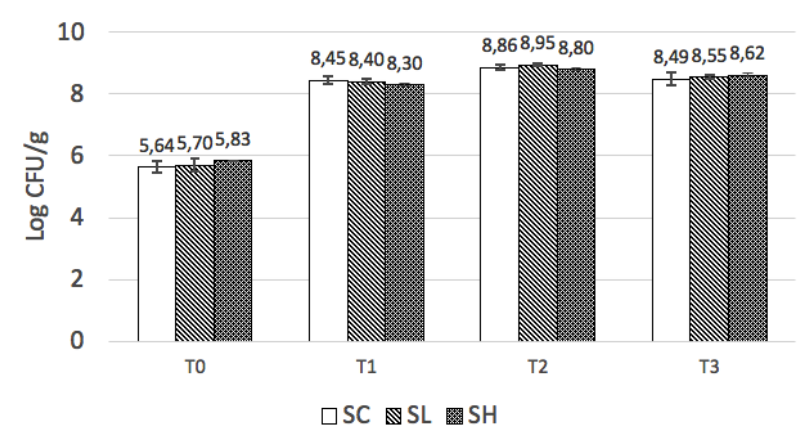

Figure 2. Micrococcaceae $(\mathrm{A})$ and lactic acid bacteria (LAB) counts $(B)$ in roe-deer salami and pork salami. SC (control: $100 \%$ pork meat); SL (low percentage: 33\% roe-deer meat and $67 \%$ pork meat; $\mathrm{SH}$ (high percentage: $50 \%$ roe-deer meat and $50 \%$ pork meat; T0 (immediately after stuffing); T1 (at 7 days storage), T2 (at 14 days storage); T3 (at 60 days storage). 
safety (Muthukumarasamy and Holley, 2006).

In regards to the products ' colour (Table 1), significant differences were found between SL and $\mathrm{SH}$ and SC. The unique colour of roe-deer meat, which is darker than pork meat, affected the lightness of the products. Similarly, the red and yellow indices were significantly higher in salami with $50 \%$ of roe-deer meat than in SC.

The acceptability of the products heavily depends on their colourimetric characteristics. Several endogenous factors contribute to the colour of meat, particularly the $\mathrm{pH}$, the type of muscle fibre, the presence of antioxidants, lipid oxidation and the mitochondrial activity in the muscles (Mancini and Hunt, 2005). Even the conditions, such as the diet of the wild animals, affect the colour of the meats (Pedrazzoli et al., 2017). The presence of roe-deer meat influenced the chemical composition (Table 2) of the products obtained, albeit mediated by the integration of pork meat, with reference to the fat content. The roe-deer meat is leaner than pork meat (Daszkiewicz et al., 2012) and SH proved to be less moist and leaner (lower percentage of lipids) than the other salamis, with a protein content between 28 and 29\%. Paleari et al. (2003) recorded substantially less protein, 18.9$20.4 \%$, in dry-cured game meat products. No differences in the $\mathrm{NaCl}$ content were detected between the groups, and the values align with data obtained from other Italian salami (Ranucci et al., 2016; Zanardi et al., 2010).

Textural profile analyses revealed that $\mathrm{SH}$ salamis were harder and gummier but presented less chewiness than the salami belonging to the other two groups (Table 3 ). The characteristics of the chemical composition of SH, leaner then SL and SC, could be the reason for these findings (Gómez and Lorenzo, 2013). The instrumental texture of the products corroborated the sensory texture (Table 4).

The sensory analyses confirmed the difference in the lightness and redness intensity of the lean meat colour in comparison to pork, as discussed above for the instrumental colour measurements, but also revealed a predominant odour and flavour of game meat that was progressively evident with the increase of roe-deer meat percentage in the salami. These attributes, as well as overall flavour intensity, hardness and chewiness, may act as discriminants for consumer preference between these two products, as further analyses could demonstrate.
Table 1. Colour attributes of roe-deer salami and pork salami.

\begin{tabular}{lccccc} 
Parameter & SC & SL & SH & SEM & P \\
Lightness $\left(\mathrm{L}^{*}\right)$ & $42.38 \mathrm{a}$ & $39.22 \mathrm{~b}$ & $37.18 \mathrm{~b}$ & 0.91 & $* *$ \\
Redness $\left(a^{*}\right)$ & $10.46 \mathrm{a}$ & $11.73 \mathrm{ab}$ & $13.37 \mathrm{~b}$ & 0.61 & $*$ \\
\hline Yellowness $\left(b^{*}\right)$ & $4.82 \mathrm{a}$ & $4.92 \mathrm{ab}$ & $5.29 \mathrm{~b}$ & 0.30 & $*$ \\
\hline
\end{tabular}

SC (control:100\% pork meat); SL (low percentage: 33\% roe-deer meat and 67\% pork meat; SH (high percentage: 50\% roe-deer meat and 50\% pork meat; SEM (standard error of the mean); Different letters in the same row reveal a difference in the mean values at ${ }^{*} \mathrm{P}<0.05,{ }^{* *} \mathrm{P}<0.01$.

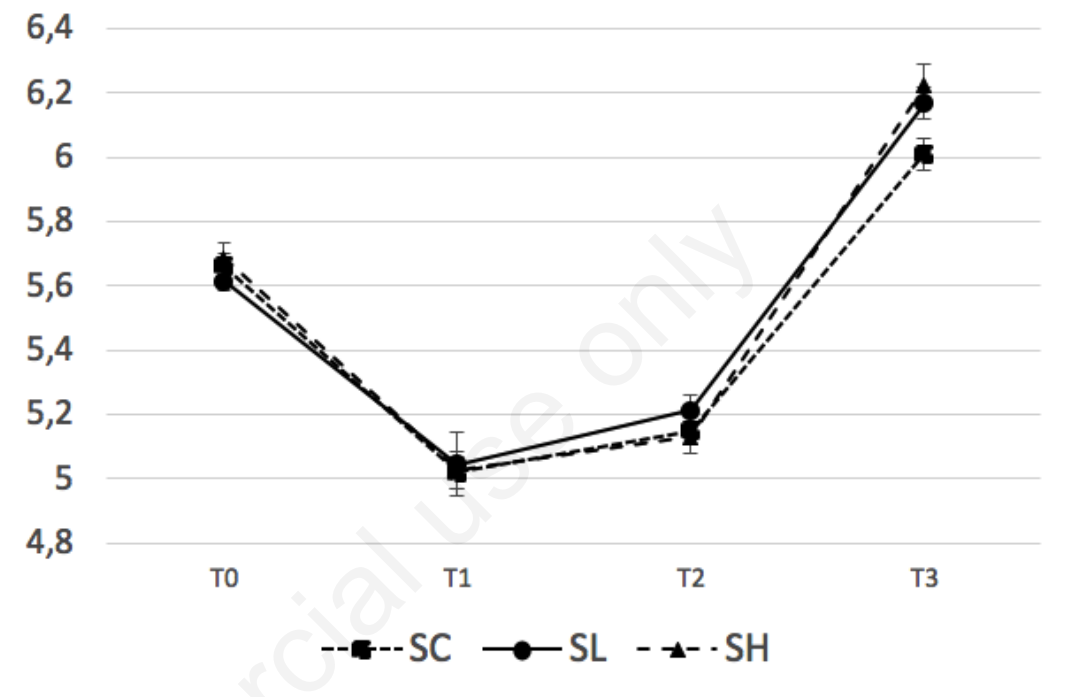

Figure 3. $\mathrm{pH}$ values in roe-deer salami and pork salami (mean values and standard deviation). SC (control:100\% pork meat); SL (low percentage: 33\% roe-deer meat and $67 \%$ pork meat; $\mathrm{SH}$ (high percentage: $50 \%$ roe-deer meat and $50 \%$ pork meat; T0 (immediately after stuffing); T1 (at 7 days storage), T2 (at 14 days storage); T3 (at 60 days storage).

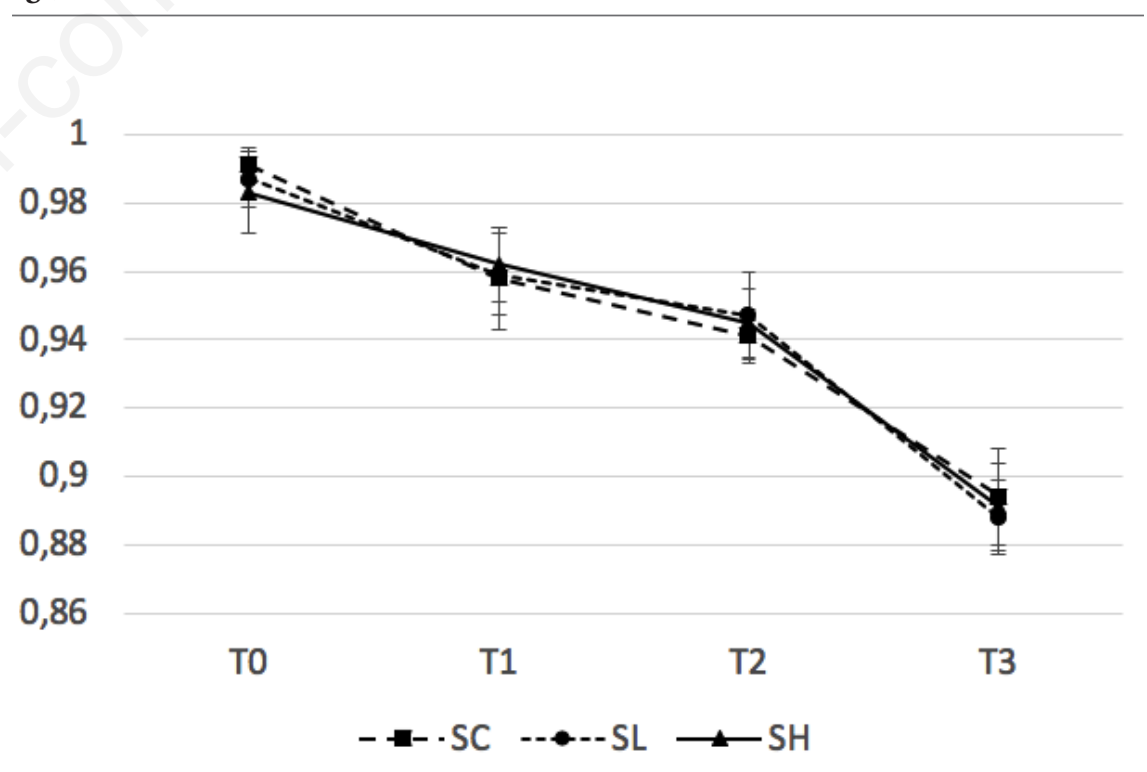

Figure 4. Water activity $\left(a_{w}\right)$ values in roe-deer salami and pork salami (mean values and standard deviation). SC (control:100\% pork meat); SL (low percentage: $33 \%$ roe-deer meat and $67 \%$ pork meat; $\mathrm{SH}$ (high percentage: $50 \%$ roe-deer meat and $50 \%$ pork meat; T0 (immediately after stuffing); T1 (at 7 days storage), T2 (at 14 days storage); T3 (at 60 days storage). 


\section{Conclusions}

The production of fermented meat products could be a valuable and sustainable strategy for the commercialisation of hunted roe-deer meat, as salami could be appre- ciated by the consumers. The roe-deer salami could be considered safe if proper management of the production chain, form hunting to processing, is hygienically implemented. Moreover, the percentage of game meat could be calibrated according to the

Table 2. Chemical composition of roe-deer salami and pork salami.

\begin{tabular}{lccccc} 
\% & SC & SL & SH & SEM & P \\
Moisture & $29.38 \mathrm{~b}$ & $29.52 \mathrm{~b}$ & $28.00 \mathrm{a}$ & 0.22 & $*$ \\
Lipid & $35.61 \mathrm{~b}$ & $35.15 \mathrm{~b}$ & $30.69 \mathrm{a}$ & 0.17 & $*$ \\
\hline Protein & $27.08 \mathrm{a}$ & $27.17 \mathrm{a}$ & $29.26 \mathrm{~b}$ & 0.57 & $*$ \\
Ash & $8.03 \mathrm{a}$ & $9.68 \mathrm{~b}$ & $10.53 \mathrm{c}$ & 0.30 & $*$ \\
\hline $\mathrm{NaCl}$ & 4.28 & 4.30 & 4.25 & 0.03 & $\mathrm{~ns}$ \\
\hline
\end{tabular}

SC (control:100\% pork meat); SL (low percentage: 33\% roe-deer meat and 67\% pork meat; SH (high percentage: 50\% roe-deer meat and 50\% pork meat; SEM (standard error of the mean). Different letters in the same row reveal a difference in the mean values at $* \mathrm{P}<0.05$. ns $=$ not significant.

Table 3. Results of texture profile analyses of roe-deer salami and pork salami.

\begin{tabular}{lccccc} 
Attribute & SC & SL & SH & SEM & P \\
Hardness (g) & $2034.57 \mathrm{a}$ & $2215.33 \mathrm{a}$ & $3270.33 \mathrm{~b}$ & 7.15 & $* * *$ \\
Resilience & 0.63 & 0.61 & 0.60 & 0.01 & $\mathrm{~ns}$ \\
\hline Cohesiveness & $0.61 \mathrm{a}$ & $0.55 \mathrm{~b}$ & $0.51 \mathrm{~b}$ & 0.01 & $*$ \\
Gumminess $(\mathrm{g})$ & $2318.19 \mathrm{a}$ & $2784.89 \mathrm{~b}$ & $3521.67 \mathrm{c}$ & 79.27 & $*$ \\
\hline Chewiness $(\mathrm{g})$ & $1519.69 \mathrm{a}$ & $1409.33 \mathrm{~b}$ & $1008.00 \mathrm{c}$ & 93.42 & $*$ \\
\hline
\end{tabular}

SC (control:100\% pork meat); SL (low percentage: 33\% roe-deer meat and 67\% pork meat; SH (high percentage: 50\% roe-deer meat and 50\% pork meat; SEM (standard error of the mean). Different letters in the same row reveal a difference in the mean values at ${ }^{*} \mathrm{P}<0.05,{ }^{*} * * \mathrm{P}<0.001$. ns $=$ not significant

Table 4. Sensory descriptive analyses of roe-deer salami and pork salami.

\begin{tabular}{|c|c|c|c|c|c|}
\hline Attribute & SC & SL & SH & SEM & $\mathbf{P}$ \\
\hline \multicolumn{6}{|l|}{ Visual examination } \\
\hline Uniformity of lean & $6.08 \mathrm{~b}$ & $5.43 \mathrm{a}$ & $5.48 \mathrm{a}$ & 0.03 & $*$ \\
\hline Intensity of lean & $4.53 \mathrm{a}$ & $6.03 \mathrm{~b}$ & $6.35 \mathrm{c}$ & 0.12 & $* * *$ \\
\hline Uniformity of the fat & 3.30 & 3.13 & 3.23 & 0.04 & ns \\
\hline Intensity of the fat & 4.45 & 4.20 & 4.48 & 0.15 & ns \\
\hline Connection between lean and fat & $6.55 b$ & $5.60 \mathrm{a}$ & $5.78 \mathrm{a}$ & 0.05 & $* *$ \\
\hline Distribution of the fat & 3.56 & 3.83 & 3.90 & 0.08 & ns \\
\hline \multicolumn{6}{|l|}{ Odour } \\
\hline Spicy & 4.50 & 4.48 & 4.78 & 0.11 & ns \\
\hline Pepper & $4.60 c$ & $4.00 \mathrm{~b}$ & $3.65 \mathrm{a}$ & 0.02 & $* * *$ \\
\hline Rancid & 0.13 & 0.18 & 0.23 & 0.03 & ns \\
\hline Game meat & $0.16 \mathrm{a}$ & $3.95 \mathrm{~b}$ & $5.48 \mathrm{c}$ & 0.12 & $* * *$ \\
\hline Mould & 0.13 & 0.15 & 0.15 & 0.01 & ns \\
\hline \multicolumn{6}{|l|}{ Flavour } \\
\hline Acid & $0.40 \mathrm{a}$ & $1.05 \mathrm{~b}$ & $1.15 b$ & 0.03 & $* *$ \\
\hline Game meat & $0.10 \mathrm{a}$ & $2.36 \mathrm{~b}$ & $3.23 \mathrm{c}$ & 0.08 & $* * *$ \\
\hline Rancid & $0.13 \mathrm{a}$ & $0.20 \mathrm{a}$ & $0.40 \mathrm{~b}$ & 0.01 & $*$ \\
\hline Bitter & 0.13 & 0.20 & 0.18 & 0.01 & ns \\
\hline Salty & 4.53 & 4.40 & 4.42 & 0.04 & ns \\
\hline Mould & 0.13 & 0.13 & 0.10 & 0.01 & ns \\
\hline Pungency & $1.98 \mathrm{~b}$ & $1.48 \mathrm{a}$ & $1.57 \mathrm{ab}$ & 0.01 & $*$ \\
\hline Overall intensity & $6.63 \mathrm{a}$ & $6.68 \mathrm{a}$ & $7.38 \mathrm{~b}$ & 0.04 & $*$ \\
\hline \multicolumn{6}{|l|}{ Texture } \\
\hline Hardness & $4.50 \mathrm{a}$ & $4.75 \mathrm{a}$ & $5.95 \mathrm{~b}$ & 0.06 & $* *$ \\
\hline Gumminess & $4.18 \mathrm{a}$ & $4.40 \mathrm{ab}$ & $4.93 \mathrm{~b}$ & 0.04 & $*$ \\
\hline Chewiness & $4.55 \mathrm{c}$ & $4.20 \mathrm{~b}$ & $3.43 \mathrm{a}$ & 0.03 & $* * *$ \\
\hline Cohesiveness & $1.63 \mathrm{a}$ & $2.05 \mathrm{ab}$ & $2.50 \mathrm{~b}$ & 0.06 & $*$ \\
\hline Solubility & 1.83 & 1.93 & 1.88 & 0.05 & ns \\
\hline Fattiness & 4.83 & 5.30 & 4.98 & 0.12 & ns \\
\hline
\end{tabular}

SC (control:100\% pork meat); SL (low percentage: 33\% roe-deer meat and 67\% pork meat; SH (high percentage: 50\% roe-deer meat and 50\% pork meat; SEM (standard error of the mean); Different letters in the same row reveal difference in the mean values at ${ }^{*} \mathrm{P}<0.05,{ }^{* * P}<0.01$, ${ }^{* * *} \mathrm{P}<0.001$. ns $=$ not significant.

consumers' preference and to provide a product with comparable attributes to the common renown pork products.

\section{References}

Avagnina A, Nucera D, Grassi MA, Ferroglio E, Dalmasso A, Civera T, 2012. The microbiological conditions of carcasses from large game animals in Italy. Meat Sci 91:266-71.

AOAC, 2000. Official Methods of Analysis, 17th edn. Arlington, VA, USA: Assoc Anal Chem.

Branciari R, Balzano M, Pacetti D, Trabalza-Marinucci M, Della Casa G, Miraglia D, Capotorti A, Frega NG, Ranucci D, 2016. Dietary CLA supplementation of pigs confers higher oxidative stability to Ciauscolo and Fabriano salami produced from their meat with no negative impact on the physicochemical, microbiological and sensorial characteristics. Eur J Lipid Sci Technol 118:1475-85.

Capita R, Llorente-Marigómez S, Prieto M, Alonso-Calleja C, 2006. Microbiological profiles, $\mathrm{pH}$, and titratable acidity of chorizo and salchichón (two Spanish dry fermented sausages) manufactured with ostrich, deer, or pork meat. J Food Protect 69:1183-9.

Cenci-Goga BT, Ranucci D, Miraglia D, Cioffi A. 2008. Use of starter cultures of dairy origin in the production of Salame nostrano, an Italian dry-cured sausage. Meat Sci 78:381-90.

Cenci Goga BT, Rossitto PV, Sechi P, Parmegiani S, Cambiotti V, Cullor JS, 2012. Effect of selected dairy starter cultures on microbiological, chemical and sensory characteristics of swine and venison (Dama dama) nitrite-free drycured sausages. Meat Sci 90:599-606.

Chakanya C, Arnaud E, Muchenje V, Hoffman LC, 2018. Changes in the physico-chemical attributes through processing of salami made from blesbok (Damaliscus pygargus phillipsi), eland (Taurotragus oryx), fallow deer (Dama dama), springbok (Antidorcas marsupialis) and black wildebeest (Connochaetes gnou) in comparison to pork. Meat Sci 146:87-92.

CIE, 1976. Colorimetry 15.2. Commission Internationale de l'Eclairage. CIE ed., Wien, Austria

Daszkiewicz T, Kubiak D, Winarski R, Koba-Kowalczyk M, 2012. The effect of gender on the quality of roe deer (Capreolus capreolus L.) meat. Small Rum Res 103:169-75.

EC Regulation, 2005. Commission 
Regulation (EC) No 2073/2005 of 15 November 2005 on microbiological criteria for foodstuffs. Off $\mathrm{J}$ Eur Union L338:1-26.

Gómez M, Lorenzo JM, 2013. Effect of fat level on physicochemical, volatile compounds and sensory characteristics of dry-ripened "chorizo" from Celta pig breed. Meat Sci 95:658-66.

Hoffman LC, Wiklund E, 2006. Game and venison - meat for the modern consumer. Meat Sci 74:197-208.

ISO, 1998. Microbiology of food and animal feeding stuffs. Horizontal method for the enumeration of mesophilic lactic acid bacteria: Colony-count technique at 30 degrees C. ISO 15214:1998. International Standardization Organization ed., Geneva, Switzerland.

ISO, 2003. Microbiology of food and animal feeding stuffs. Horizontal method for the enumeration of sulfite-reducing bacteria growing under anaerobic conditions. ISO 15123:2003. International Standardization Organization ed., Geneva, Switzerland.

ISO, 2004. Microbiology of food and animal feeding stuffs. Horizontal methods for the detection and enumeration of Enterobacteriaceae. Part 2: Colonycount method. ISO 21528-2:2004. International Standardization Organization ed., Geneva, Switzerland.

ISO, 2012. Sensory analysis. General guidelines for the selection, training and monitoring of selected assessors and expert sensory assessors. ISO 8586:2012. International Standardization Organization ed., Geneva, Switzerland.

ISO, 2016. Sensory analysis. Methodology. General guidance for establishing a sensory profile. ISO 13299:2016. International Standardization Organization ed., Geneva, Switzerland.

ISO, 2017a. Microbiology of the food chain. Horizontal method for the detection and enumeration of Listeria monocytogenes and of Listeria spp. Part 1: Detection method. ISO 11290-1:2017. International Standardization Organization ed., Geneva, Switzerland.

ISO, 2017b. Microbiology of the food chain. Horizontal method for the detection, enumeration and serotyping of Salmonella. Part 1: Detection of Salmonella spp. ISO 6579-1:2017. International Standardization Organization ed., Geneva, Switzerland.

Karwowska M, Dolatowski ZJ, 2017. Effect of acid whey and freeze-dried cranberries on lipid oxidation and fatty acid composition of nitrite-/nitrate-free fermented sausage made from deer meat.
Asian Austral J Anim Sci 30:85-93.

Kuhn KG, Torpdahl M, Frank C, Sigsgaard K, Ethelberg S, 2011. An outbreak of Salmonella Typhimurium traced back to salami, Denmark, April to June 2010. Eurosurveillance 16:19863.

Lucchini R., Armani M., Novelli E., Rodas S., Masiero A., Minenna J., Bacchin C., Drigo I., Piovesana A., Favretti M., Rocca M, Zamboni U, Farina G, 2014. Listeria monocytogenes in game meat cured sausages. In: Paulsen, P, Bauer A, Smulders FJM, eds. Trends in game meat hygiene: From forest to fork. Wageningen Academic Publishers, Wageningen, The Netherlands, pp. 167174.

Mancini RA, Hunt MC, 2005. Current research in meat color. Meat Sci 71:100-21.

Mauriello G, Casaburi A, Villani F, 2002. Proteolytic activity of Staphylococcus xylosus strains on pork myofibrillar and sarcoplasmic proteins and use of selected strains in the production of 'Naples type' salami. J Appl Microbiol 92:48290.

Miraglia D, Ranucci D, Trabalza-Marinucci M, Acuti G, Forte C, Codini M, Roila R, Branciari R, 2017. Microbiological, chemical-physical and sensory characteristics of Fabriano salami from pigs fed Oregano vulgaris extract. It J Food Sci 6:6906.

Muthukumarasamy P, Holley RA, 2006. Microbiological and sensory quality of dry fermented sausages containing alginate-microencapsulated Lactobacillus reuteri. Int J Food Microbiol 111:164-9.

Paleari MA, Bersani C, Vittorio MM, Beretta G, 2002. Effect of curing and fermentation on the microflora of meat of various animal species. Food Control 13:195-7.

Paleari MA, Moretti VM, Beretta G, Mentasti T, Bersani C, 2003. Cured products from different animal species. Meat Sci 63:485-9.

Paulsen P, Smulders FJM, Hilbert F, 2012. Salmonella in meat from hunted game: A Central European perspective. Food Res Int 45:609-16.

Pedrazzoli M, Dal Bosco A, Castellini C, Ranucci D, Mattioli S, Pauselli M, Roscini V, 2017. Effect of age and feeding area on meat quality of wild boars. It J Anim Sci 16:353-62.

Połka J, Rebecchi A, Pisacane V, Morelli L, Puglisi E, 2015. Bacterial diversity in typical Italian salami at different ripening stages as revealed by high-throughput sequencing of $16 \mathrm{~S}$ rRNA amplicons. Food Microbiol 46:342-56.

Quirós-Fernández F, Marcos J, Acevedo P,
Gortázar C, 2017. Hunters serving the ecosystem: the contribution of recreational hunting to wild boar population control. Eur J Wildlife Res 63:57-63.

Ramanzin M, Amici A, Casoli C, Esposito L, Lupi P, Marsico G, Mattiello S, Olivieri O, Ponzetta MP, Russo C, Trabalza Marinucci M, 2010. Meat from wild ungulates: ensuring quality and hygiene of an increasing resource, It J Anim Sci 9:e61.

Ranucci D, Branciari R, Acuti G, Della Casa G, Trabalza-Marinucci M, Miraglia D, 2013. Quality traits of Ciauscolo salami from meat of pigs fed rosemary extract enriched diet. It J Food Saf 2:e16.

Ranucci D, Loschi AR, Miraglia D, Stocchi R, Branciari R, Rea S, 2016. Effect of selected starter cultures on physical, chemical and microbiological characteristics and biogenic amine content in protected geographical indication Ciauscolo salami. It J Food Saf 5:5568.

Ranucci D, Miraglia D, Branciari R, Morganti G., Roila R, Zhou K, Jiang H, Braconi P, 2018. Frankfurters made with pork meat, emmer wheat (Triticum dicoccum Schübler) and almonds nut (Prunus dulcis Mill.): evaluation during storage of a novel food from an ancient recipe. Meat Sci 145:440-6.

Soriano A, Cruz B, Gómez L, Mariscal C, Ruiz AG, 2006. Proteolysis, physicochemical characteristics and free fatty acid composition of dry sausages made with deer (Cervus elaphus) or wild boar (Sus scrofa) meat: A preliminary study. Food Chem 96:173-84.

Tomasevic I, Novakovic S, Solowiej B, Zdolec N, Skunca D, Krocko M, Nedomova S, Kolaj R, Aleksiev G, Djekic I, 2018. Consumers' perceptions, attitudes and perceived quality of game meat in ten European countries. Meat Sci 142:5-13.

Wang X, Ren H, Wang W, Zhang Y, Bai T, Li J, Zhu W, 2015. Effects of inoculation of commercial starter cultures on the quality and histamine accumulation in fermented sausages. J Food Sci 80:M377-84.

Zanardi E, Ghidini S, Battaglia A, Chizzolini R, 2004. Lipolysis and lipid oxidation in fermented sausages depending on different processing conditions and different antioxidants. Meat Sci 66:415-23.

Zanardi E, Ghidini S, Conter M, Ianieri A, 2010. Mineral composition of Italian salami and effect of $\mathrm{NaCl}$ partial replacement on compositional, physicochemical and sensory parameters. Meat Sci 86:742-7. 